\title{
Intellectual Capital, Female Manager Innovative Behavior and Catering Business Performance
}

\author{
Salma Abdullah ${ }^{1}$ and Ampauleng ${ }^{2}$ \\ ${ }^{1,2}$ Sekolah Tinggi Ilmu Ekonomi Makassar (STIEM) Bongaya, Indonesia \\ Email address: \\ stiem.salmabdullah@yahoo.com; ampauleng@gmail.com
}

\begin{abstract}
The problem of the catering business is that tastes tend to be less tasty, mistakes in choosing non-quality cooking ingredients, and employees (chefs) tend not to be painstaking, so it is interesting to research by investigating the relationship of intellectual capital with the innovative behavior of women managers and impacting on business performance through competitive advantage. From 25 catering businesses headed by women managers, we set managers and employees (cooks) as 75 respondents (purposive sampling) with data analysis using WarpPLS 7.0. We found that the better the intellectual capital, the better the innovative behavior of female managers, and the better the catering business performance in Makassar City. We found that the better the intellectual capital, the better female managers' innovative behavior, and the better the catering business performance in Makassar City. We also find that behavior innovation is getting better so that this business has a competitive advantage and good business performance.
\end{abstract}

Keywords: Intellectual capital, innovative behavior, competitive advantage, business performance.

\begin{abstract}
Abstrak: Masalah bisnis catering adalah cita rasa cenderung kurang lezat, kesalahan memilih bahan masakan tidak berkualitas dan karyawan (koki) cenderung tidak telaten, sehingga menarik untuk dilakukan penelitian dengan cara menginvestigasi hubungan modal intelektual dengan perilaku inovatif manajer wanita dan berdampak pada kinerja bisnis melalui keunggulan kompetetif. Dari 25 bisnis catering dinahkodai oleh manajer wanita sehingga kami menetapkan manajer dan karyawan (koki) sebagai responden sebanyak 75 (purposive sampling) dengan analisis data menggunakan WarpPLS 7.0. Kami menemukan bahwa semakin baik modal intelektual semakin baik perilaku inovatif manajer wanita dan semakin baik kinerja bisnis catering di Kota Makassar. Kami menemukan pula bahwa perilaku inovatif semakin baik sehingga bisnis ini memiliki keunggulan kompetetif dan kinerja bisnis menjadi baik.
\end{abstract}

Kata kunci: Modal intelektual, perilaku inovatif, keunggulan kompetetif, kinerja bisnis. 


\section{INTRODUCTION}

Some SMEs in Makassar City tend to choose the catering business as their mainstay business. Anyone may run the easiest promising business. Opening a catering business is enough to take advantage of the existing kitchen and the raw materials are easily obtained (Kurnia, 2014). Although this business tends to be easy to do and easy to get raw materials, this business still has several problems. For example, the taste is not yet delicious or it doesn't suit the customer's tongue, sometimes the selection of ingredients is not good quality. And finally, employees (chefs) tend not to be painstaking in cooking, as a result, they have no competitiveness. What this business actor does is create competitive attributes through flavors that match the customer's tongue, not the manager's tongue. Also, it requires patience by employees (chefs) in cooking with the assumption that they can produce fresh and quality ingredients. Some of these business phenomena are interesting to do research on.

Business actors must have intellectual capital or potential intellectual capital so that their business continues to exist and fly in the market. Intellectual capital increases innovation (such as flavor, aroma, and texture) that may impact business performance (Joshi et al., 2012; Mondal and Ghosh, 2012). Therefore, intellectual capital is the most significant and strategic asset to gain a sustainable competitive advantage for a company (Maditinos et al., 2011) and good business performance (Kamukama et al., 2011). Many women work in this business. Many questions in this business include: how are the innovative behaviors of female managers in managing a catering business that has a competitive advantage and has the taste, aroma, and texture of food?

This research argues that the role of intellectual capital determines the innovative behavior of female managers. Also, female managers differ from male managers in the quality of job personality, especially in innovation. Female managers are more transformational than male managers (Sumail and Abdullah, 2019). Often female managers display job behavior that is oriented towards competitiveness, while male managers are sometime ignored on the job.

Therefore, this study aims to determine the relationship between intellectual capital and female manager behavior in the catering business in Makassar City. The central issue of this study is the innovative behavior of female managers in managing a catering business. (Sweida and Reichard, 2013); (Wynarczyk, 2010) states that women's participation in the MSME sector is very high and competitive, and the result is good business performance. Female manager innovative behavior is more ethical, gentler, show empathy, sensitive to other (Valentine et al., 2019), also create an innovational attitude. In contrast, male managers often display attitudes that ignore the feelings of others.

As a contribution to the literature, we place the competitive advantage variable as the mediating variable. Because, competitive advantage is a portrait that the company has good performance (Sölvell, 2015). Therefore, the better the competitive advantage, the better the business performance.

This article consists of theoretical study, methodology, research result, discussion, and conclusion. 


\section{THEORETICAL REVIEW}

An independent region will be healthy and advances if the industrial sector is strong and has secure and sustainable competitiveness (Demirbag et al., 2006), such as the SMEs catering industry. In the past, (Porter, 1990) stated that the concept of competitiveness would only be meaningful if in the shutter of competition. Without the presence of competition, competitiveness will lose its importance (Lakhal, 2009). Obtaining the quality of intellectual capital and innovative manager behavior would not lose the meaning and the rhythm of competition business performance.

As the market dynamics is full of competitive aromas, intellectual capital becomes a knowledge-based business. The essence of knowledge-based business is innovative and capable business and competitiveness so that business performance will be good and quality (Namvar et al., 2010; Sydler et al., 2013).

Therefore, the female managers encourage the role of intellectual capital significantly. Motivation to innovate is significant because it is equipped with quality intellectual capital. Moreover, female managers perceive more successful business than male managers (Lee et al., 2010). Some researchers have reported that the better intellectual capital, the better innovation. Such as, (Chou et al., 2018); (Han and Li, 2015); (Örnek and Ayas, 2015); (Subramaniam and Youndt, 2005). Hence, the proposed hypothesis is:

\section{H1. Intellectual capital is related to the innovative behavior of female managers.}

It emphasized that excelled female managers' innovative role is better than male managers, mostly they are more sensitive to business growth (Kariv, 2012). Female managers can create an inclusive work environment and create stability in all aspects of the operation so that the potential for better business performance is wide open. Often, female managers are interested in the social aspect of maintaining their image in the eyes of consumers and are smart in placing themselves in favorable work situations so that their appearance is different from that of men (Achtenhagen and Tillmar, 2013; Brinia, 2012). Several management researchers have found that the better the innovative behavior, the better the business performance. For example, (Al-ansari et al., 2013); (Örnek and Ayas, 2015); (Özmutaf et al., 2015); (Sumail and Abdullah, 2019). Therefore, the hypothesis put forward is:

\section{H2. Female manager's innovative behavior is related to business performance.}

It cannot deny, that the number one spearhead of a business's success is managers who perform well through innovative roles. It takes commitment, motivation, and talent by managers. Female managers are innovative managers who can keep up with the competitive business in the market. It ascertained that female managers capture the sound of competition through the innovation process (Carrasco, 2014). The content of a sense of competition (Katarzyna, 2015: Krugman, 1996) and entrepreneurial mentality (Chasaki, 2017) competitive is the characterize innovative behavior te, so that female managers have strong confidence in improving business performance. Besides having a sense of competition and having an entrepreneurial mentality, innovation manifests female managers. The ability to 
think and imagine is human nature as intelligent living beings (Kurnia, 2014). Hence, the better the innovative behavior of women, the better the competitive advantage (Al-ansari et al., 2013; Katarzyna, 2015; Nadia et al., 2016). Therefore, the hypothesis put forward is:

\section{H3. The innovative behavior of female managers is related to competitive advantage.}

Competitive advantage is a portrait of creating a unique value that exceeds its competitors, such as designing taste, aroma, and texture so that the results of business performance are good. At least, female managers can capture market messages so that they can maintain better business performance. There are several steps to maintain competitive advantage, namely 1) conducting audits to identify value-adding rather than value-added processes, 2) designing and implementing improvements to value-adding processes, 3) measuring process performance, and 4) measuring sustainability improvements (Diana et al., 2015). The better the competitive advantage, the better the business performance (Davcik and Sharma, 2016; Ejrami et al., 2016; Wahyuni and Ng, 2012). Because of that, the hypothesis proposed is:

H4. Competitive advantage is related to business performance.

H5. The innovative behavior of female managers related to business performance is mediated by competitive advantage.

\section{METHODS}

We identified 27 catering businesses in Makassar City and 25 which were headed by female managers. In addition to female managers, we assigned two employees (chefs) as a source of information (purposive sampling) so that the respondents were 75 respondents. The reason is that they know for sure about the innovative behavior of the female managers in their place of work. Each variable uses indicators and sets a Likert Scale as the instrument to measure the questionnaires. Furthermore, the data collected was analyzed using WarpPLS 7.0 .

\section{RESULTS}

Respondent profile. Female managers headed this business, and most of the employees are female involved in product processing, $76 \%$ female and $24 \%$ male employees. Generally, women are more ethical concerning quality control of work and higher altruism than men (Valentine et al., 2009). We found that all-female managers were married and a small proportion of employees were not married. The success of female managers, there is the husband role is to support with a bright idea (Nikina et al., 2015).

Generally, the age of managers and employees are between 25-40 years old is 63\%) and over 40 years old are $37 \%$. They mostly have the experience, especially experience dealing with business risks. Because this business has high risk: the risk of perishability, female managers tend to be risk-neutral (Maxfield et al., 2010). Although armed with a high school education of 96 percent, managers and employees remain innovative, and 4 percent 
are undergraduate. Indeed, the right education can help them find sources of innovative ideas and turn these ideas into bright and well-performing companies (Bhardwaj, 2014).

Model Goodness. We use three model measurement indicators, namely Average path coefficient (APC), Average R-squared (ARS), and Average adjusted R-squared (AARS). The Average path coefficient (APC) value is 0.438 (see Table 1). The average path coefficient is close to $50 \%$, so it stated that the explanatory (independent) variable responds to the dependent variable. Furthermore, the mean determinant correlation or Average Rsquared $(\mathrm{ARS})=0.417$ is below $50 \%$. It between variables to correlate.

Table 1. Model Goodness

\begin{tabular}{lccc}
\hline \multicolumn{1}{c}{ Measurement indicator } & Fit Criteria & Analysis result & Information \\
\hline Average path coefficient (APC) & $\mathrm{p}<0,05$ & $0.438,(\mathrm{p}=0.001)$ & Good \\
Average R-squared (ARS) & $\mathrm{p}<0,05$ & $0.417,(\mathrm{p}=0.001)$ & Good \\
Average adjusted R-squared & $\mathrm{p}<0,05$ & $0.305,(\mathrm{p}=0.001)$ & Good \\
(AARS) & & &
\end{tabular}

Note: the level of significance p-value $\alpha 0.05$

The correlation value of several independent variables is below $50 \%$, as the value of the Average adjusted R-Squared (AARS) is 0.305 .

However, the three indicators of the goodness of this model have a p-value of $\mathrm{P}<0.001$. Therefore, Models Goodness explained the data (Sumail and Abdullah, 2019).

Combined Loadings and Cross Loadings. Table 2, presents data on combined loadings and cross-loadings information. The goal is to cross-check whether the indicator is valid or reliable and the cross-check is met. All indicators were declared valid because factor load> cross-loadings or $\mathrm{p}<0.001$, the reliability were met because composite reliability coefficients> Cronbach's alpha coefficients (Solimun et al., 2017). Combined loadings and cross-loadings can also be used as a standard measurement of the most important or strongest indicators for reflecting a variable.

Table 2. Combined Loadings and Cross Loadings

\begin{tabular}{lcc}
\hline & $\begin{array}{c}\text { Combined } \\
\text { Loadings }\end{array}$ & P value \\
\hline $\begin{array}{l}\text { Intellectual capital (reliability coefficients }=\mathbf{0 . 7 4 9}>\boldsymbol{\alpha}=\mathbf{0 . 6 0 8}), \\
\text { with indicator: }\end{array}$ & & \\
Human capital & 0.804 & $<0.001$ \\
Structural capital & 0.556 & $<0.001$ \\
Relationship capital & 0.746 & $<0.001$ \\
The innovative behavior of female managers (reliability & & \\
coefficients $=\mathbf{0 . 7 7 0}>\boldsymbol{\alpha}=\mathbf{0 . 7 5 2})$, with indicator: & & \\
Curiosity & 0.771 & $<0.001$ \\
Entrepreneurial mind & 0.674 & $<0.001$ \\
Sense of competition & 0.732 & $<0.001$ \\
Competitive advantage (reliability coefficients $=\mathbf{0 . 8 0 1}>\boldsymbol{\alpha}=$ & & \\
$\mathbf{0 . 6 6 6})$, with indicator: & &
\end{tabular}




$\begin{array}{lcc}\text { Rare } & 0.690 & <0.001 \\ \text { Worth } & 0.827 & <0.001 \\ \text { Cannot duplicate or copy } & 0.734 & <0.001 \\ \text { Not substitutable } & 0.568 & <0.001 \\ \text { Business performance (reliability coefficients }=\mathbf{0 . 7 7 2}>\boldsymbol{\alpha}=\mathbf{0 . 7 3 9}), & & \\ \text { with indicator: } & & \\ \text { Sales growth } & 0.944 & <0.001 \\ \text { Profitability } & 0.589 & <0.001 \\ \text { Market share } & 0.622 & <0.001 \\ \text { Information: } \mathrm{n}=75 \text {. The results of the cross check turned out that all indicators were declared } \\ \text { valid and reliabel. }\end{array}$

The most prominent indicator in reflecting intellectual capital is human capital 0.804 and the indicator of relationship capital and structural capital. It means that managers and employees can find ways to innovate and ultimately increase profits.

We found that curiosity was the most significant indicator, reflected on female managers' innovative behavior (0.771) and followed by a sense of competition and entrepreneurial mentality. It means that female managers and employees have a curiosity or curiosity that can serve as an impetus for creation or innovation. (Harvey et al., 2009) reported that female curiosity tended to be high. The need for women to highlight achievement behavior is very high. They don't even want to be left behind with men. (Aramand, 2013) explains that females place themselves in a high entrepreneurial position when compared to men.

Innovation can drive a competitive advantage. We found that the most significant indicator in reflecting competitive advantage is that the product has a value from customer perception of 0.827 , then following indicators cannot be imitated, rare or unique, and cannot be substituted. Customers perceive that the products produced by this business have different tastes and suit the taste buds so that they have a competitive advantage.

The value inherent in competitive advantage will drive good business performance and quality. In the catering business, the business performance indicator that is the highest weight is sales growth of 0.944 , followed by market share and profitability. It means that there is a tendency for this business to have growth power.

Table 3. Result of path coefficients

\begin{tabular}{|c|c|c|c|c|c|c|}
\hline \multicolumn{2}{|c|}{ Explanatory variable } & \multicolumn{2}{|c|}{ Response variable } & Direct influence & p-value & Information \\
\hline \multicolumn{2}{|c|}{ Intellectual capital (IC) } & \multicolumn{2}{|c|}{$\begin{array}{l}\text { The innovative behavior of } \\
\text { female managers (IF) }\end{array}$} & $0.463 * * *$ & $<0.001$ & $\begin{array}{l}\text { highly } \\
\text { significant }\end{array}$ \\
\hline \multirow{2}{*}{\multicolumn{2}{|c|}{$\begin{array}{l}\text { The innovative behavior of } \\
\text { female managers (IF) } \\
\text { The innovative behavior of } \\
\text { female managers (IF) }\end{array}$}} & \multicolumn{2}{|c|}{$\begin{array}{l}\text { Business performance } \\
\text { (BP) }\end{array}$} & $0.193 * *$ & 0.040 & significant \\
\hline & & \multicolumn{2}{|c|}{$\begin{array}{l}\text { Competitive advantage } \\
\text { (CA) }\end{array}$} & $0.517 * * *$ & $<0.001$ & $\begin{array}{l}\text { highly } \\
\text { significant }\end{array}$ \\
\hline \multicolumn{2}{|c|}{ Competitive advantage (CA) } & $\begin{array}{l}\text { Busir } \\
\text { (BP) }\end{array}$ & performance & $0.579 * * *$ & $<0.001$ & $\begin{array}{l}\text { highly } \\
\text { significant }\end{array}$ \\
\hline $\begin{array}{l}\text { Explanatory } \\
\text { variable }\end{array}$ & \multicolumn{2}{|c|}{$\begin{array}{l}\text { Mediating } \\
\text { variables }\end{array}$} & $\begin{array}{l}\text { Response } \\
\text { variable }\end{array}$ & $\begin{array}{l}\text { Indirect } \\
\text { influence }\end{array}$ & p-value & $\begin{array}{c}\text { The nature of } \\
\text { mediation }\end{array}$ \\
\hline $\begin{array}{l}\text { The innovative } \\
\text { behavior of female } \\
\text { managers (IF) }\end{array}$ & \multicolumn{2}{|c|}{$\begin{array}{l}\text { Competitive } \\
\text { advantage (CA) }\end{array}$} & $\begin{array}{l}\text { Business } \\
\text { performance } \\
(\mathrm{BP})\end{array}$ & $0.300 * * *$ & $<0.001$ & $\begin{array}{c}\text { Partial } \\
\text { mediation }\end{array}$ \\
\hline
\end{tabular}




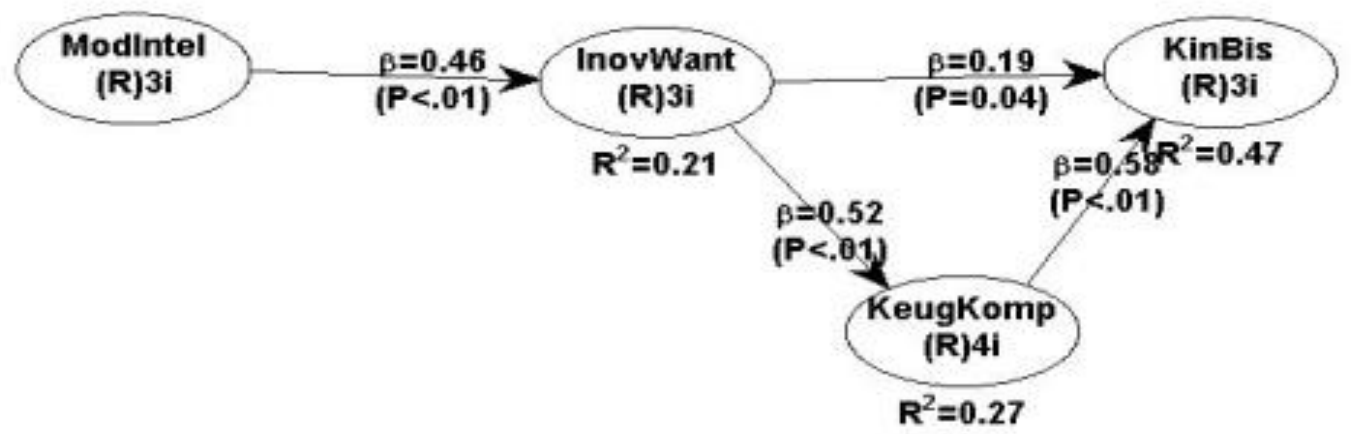

Figure 1. Research result model

Table 3 and Figure 1 are portraits of information on the relationship between variables. First is the direct relation that intellectual capital has a positive and significant effect on female managers' innovative behavior $(\beta=0.463, \mathrm{p}<0.001$ or high significance) because the $\mathrm{p}$-value is more significant than 0.05 obtains empirical support. The innovative behavior of female managers has a positive and significant effect on business performance $(\beta=0.193$, $\mathrm{p}<0.001$ or high significance) that stated to have empirical support. The female managers' innovative behavior is positive and significant related to competitive advantage $\beta=0.517$, $\mathrm{p}<0.001$ or high significance) and has empirical support. Furthermore, competitive advantage has a positive and significant relationship with business performance $(\beta=0.579$, $\mathrm{p}<0.001$ or highly significant) and has empirical support. Second, the indirect relationship: the innovative behavior of female managers has a positive and significant effect on business performance mediated by competitive advantage $(\beta=0.300, p<0.001)$, with the nature of the mediation being partial mediation and receiving empirical support.

Partial mediation is said because the value of the relationship between intellectual capital and business performance after there is a competitive advantage, the coefficient value has decreased to $\beta=0.300$. Before there was a role for competitive advantage, the relationship between intellectual capital and business performance tended to be strong or high, namely $\beta=0.46$.

\section{DISCUSSION}

We found that the better the intellectual capital, the better the innovative behavior of female managers. Because female managers tend to have satisfied human capital, they can innovate, and the result is competitiveness and good business performance. Human capital is the lifeblood in intellectual capital (Wang et al., 2014). It is where the source of innovation and improvement is. Female managers can choose the healthy intake source who will give birth to a high level and qualified lifeblood. Therefore, female managers often show 
strategic ways of thinking or mega thinking. The orientation is to provide results in the form of benefits and values for consumer needs.

Strategic thinking or mega thinking by female managers is to change the facts to suit consumer needs. Previously, taste measurement was based on the manager's tongue which resulted in low competitiveness. The female manager can smell customer tastes, and she turns the taste standard from the manager's to the customer's utterances. The implication of the importance of this turnaround attitude is to arouse customer demand. In the catering business, people must understand the desire of customers' products. The customer behavior requests are different and unique from one another. Therefore, female managers understand significantly. From the standard of customer's tongue, the demand was high enough, convinced that the brand of catering product goes well as the catering business is popular. That is the reason why female managers need to understand more deeply customer demand behavior.

It is not enough for female managers to rely solely on knowledge management skills. However, a role for relational capital (rational capital) is required for innovative behavior. It is reasonable to reason that a harmonious relationship with customers can increase sales and expand business knowledge (Bellora et al., 2013). Therefore, the more connections and relations, the less room for business problems. To solve the business problems by building a productive and quality communication atmosphere. Often, female managers can vocalize cool, inviting, and strong communication. Therefore, in managing communication with other parties, female personal quality managers tend to be calm, pleasant, and have strong intentions. Reports from (Yaseen et al., 2016) indicated that female managers were slightly delightful, attractive, and intentional than male. The reason is a female business manager is happy with work behavior that is oriented towards competitiveness and likes to learn from others, while the male manager is on duty. Departing from the difference in orientation, it is not an exaggeration that female managers are superior in managing the business, especially the catering business when compared to male managers.

Often female managers engage and exchange knowledge and experience in a two-way manner with others. The goal is to produce accurate information. Information is a powerful weapon in today's information age and super-fast change. The sooner the information is obtained, the faster the female manager can analyze the changes that occurred. For example, the changes in customer taste that the more quickly and adaptively the female managers respond to these changes. Consequently, when a female manager has no information, she would be immobilized to understand the changes that occurred. Illustrating it can be seen that the attitude of female managers continues to seek information is a vital success factor in managing this business. Values and information-seeking behavior are closely related to relational capital.

We believe that the female manager's seriousness is significant in realizing a harmonious relationship with the catering business customers. This sincerity is from the strong attain and never-ending intention of selling products. The relationship of business is not limited to a short term relationship but a long term business. Also, a female manager builds a relationship with business customers is a synergistic relationship and the relationship lasts a long time. For female managers, business customers are the sun, encouragement which continues to exist and fly in the same industrial market on its journey of life. Therefore, female managers are serious about managing this business. As a proven, 
the serious female manager can find a talented chef, skilled in preparing ingredients to produce delicious flavors. Thus, the implications of the role of relational capital are significant for female managers' innovative behavior.

Although the contribution tends to be low if compared to the components of human capital and relational capital, we also find that what strengthens intellectual capital by female managers in the catering business is structural capital. Played by the female manager, the ability to convince the company that the innovation carried out has added value (Lópezet al., 2014). We also found nodes of innovation that are different from the fast-food restaurant business. There are things they can $\mathrm{d}$, but that fast food restaurant businesses cannot do. These business actors have structural capital that comes from the habit of cooking in the kitchen. Then they do several experiments to produce innovations that are under customer tastes. They realize that customer tastes develop very dynamically. Their dream is to be a pioneer in this business to focus on customer needs, not on competitors. Therefore, they always try to get ahead of the competitors' game and make this business the first choice.

Female managers use intellectual capital as nutrition to avoid this business problem. For example, the taste is not yet delicious or not according to the customer's tongue, sometimes the selection of ingredients is not qualified, and the chef tends not talented in cooking, the result, the potential for customers to move to other products. Besides, female managers always assist, especially the chefs to not careless in the cooking process. The risk of the chef's actions may result in losing the business. Choosing the right employee (chef) who has the experience and cooking talent is an effort in the catering business.

It cannot deny that intellectual capital is the result of the human construction mind have good values. Intelligent minds can generate bright ideas and have a great desire to achieve the best results. To achieve the best results, female managers in this business tend to have innovative talents. (Bhardwaj, 2014) states that the right education can help them find innovative sources of ideas and turn into bright and well-performing companies (Bhardwaj, 2014). Impressively, this business actor only has a formal high school education of 96 percent. They can do innovative work that is competitive. This fact is in line with the statement by (Goleman, 2002) that intellectual intelligence only contributes 20 percent in determining the success of a business, the rest is contributed by other variables, such as innovative talent. It means that the level of education is not a determining factor in managing this business.

Intellectual capital will have meaning if the innovative behavior of female managers results in acceptable and competitive innovation. Female managers have a sense of curiosity or curiosity in making innovations. The curiosity emotion of the committee encourages the source to be creative in competitiveness and good business performance. (Harvey et al., 2009) reported that women's curiosity tended to be high. Curiosity is the answer in the form of a bright idea (Kurnia, 2014). Often he does experiments with employees (chefs) in preparing dishes that produce delicious flavors and are different from others or other businesses. It is a brilliant idea as a raw material or nutrition in doing innovative work. Therefore, curiosity is the most valuable resource in driving primary initiatives, and the example is innovation.

Also, female managers' curiosity shows personal behavior and have a sense of competition and entrepreneurial mentality. Through a sense of competition, female managers reveal the ability to create bright ideas in managing a catering business. It is 
because of the support of intellectual capital. Female managers often develop their creativity. There is even a great willingness to accept new ideas (open-mindedness). Female managers who are open-minded tend to have a belief and attitudes in knowledge and viewing other business. Having good business knowledge and viewing business is the raw material for compiling the anatomy of a new idea to produce innovations that have different values of customers. We believe that businesses that have different values from the other business of the market.

Intellectual capital will have meaning if the innovative behavior of female managers results in excelled and competitive innovation. Female managers have a sense of curiosity or curiosity in making innovations. The committee manager's curiosity emotions are a source of encouragement to be creative to excel in business competitiveness and performance. (Harvey et al., 2009) reported that women's curiosity tended to be high. The interest can be likened to a long journey so that thirst and anxiety are felt to get a definite answer in the form of a bright idea (Kurnia, 2014). Often he does experiments with employees (chefs) in preparing dishes that produce delicious flavors and are different from those produced by other business people. It is a brilliant idea as a raw material or nutrition in doing innovative work. Therefore, innovation is one of the curiosity or interest which is the most valuable resource in driving considerable initiatives.

In addition to curiosity, female managers show personal behavior with a sense of competition and have an entrepreneurial mentality. Through a sense of competition, female managers showed the ability to create bright ideas in managing a catering business. It is because of the support of intellectual capital. Female managers often develop their creativity. There is even a great willingness to accept new ideas (open-mindedness). Openminded behavior is related to the belief and attitudes of a female manager. Her knowledge compiles the anatomy of a new idea to produce innovations. We believe that some business has different values will win in the market.

This business market is getting tougher and hypercompetitive. Therefore, it is necessary to have a female manager who has an entrepreneurial personality towards new and qualified ideas. Quality innovation if there is a content of creativity development. Because the female manager has an entrepreneurial mind, the creativity displayed has new and proficient. We observed that women managers in this business tend to be creative. They love new possibilities that have never existed before. On the other side, they do not like to create the same thing over and over again. They don't even want to follow established rules because they want something different from what other businesses are doing. That is the reason for the turn-around strategy from the manager's taste to the customer's appetite. This business has new and qualified values, so the products produced are a competitive business, and the business performance is good. Therefore, this study supports the hypothesis reported by (Chou et al., 2018); (Han and Li, 2015); (Örnek and Ayas, 2015); (Subramaniam and Youndt, 2005) stated that the better the intellectual capital, the better the innovative behavior, especially female managers.

In managing the catering business, a female manager must have unique qualities to pursue the best performance. Doing the best job is a fundamental attitude to be the best in whatever he does. By always being the best, he can dedicate and present the best to the company. 
To achieve the best work results, female managers continuously make selfimprovement. Therefore, women managers are treated dynamically as a mental attitude for not complacent with each work achieved. This mental attitude makes it possible for female managers to have a sense of urgency and not easily get caught in the comfort zone to produce the best performance. Ideally, the business actor may change the need based on a holistic and sensible perspective. The decision is significant as the prerequisite for the change related to changing customer needs.

The catering business filled with demands for excellent performance. The demand is an encouragement to capture in a comfort zone, the goal is to work with excellent ability.

The role of innovative female managers is more excellent and more sensitive than a male manager (Kariv, 2012). Also, we proved that the catering business with a female manager was doing well. It is because sales growth tends to increase from year to year. Sales growth is a portrait that the trend of the market or consumer demand is high. Indeed, female managers can create an inclusive work environment and stability of operational, so that the potential for better business performance is wide open. Often, female managers are interested in the social aspects of maintaining their image in the eyes of consumers and are smart in placing themselves in favorable work situations so that their appearance is different from that of men (Achtenhagen and Tillmar, 2013; Brinia, 2012). The innovative work of female managers is manifested in a strong market share position. The role of creative behavior and development of excelled management, and curiosity or a sense of notification are the primadonnas of innovative female managers in the catering business.

The potential to market this business product is quite substantial in Makassar City because it has a population of 1.5 million. Therefore, it is the reason that this business is a mainstay business because it has a sizeable enough market potential. The catering business has a vigorous market share with other food industries. With the ability to increase sales growth and strengthen market share, the implication is that business performance is getting better. Because this business has robust sales growth and market share, the business profitability is quite good. The ability to generate profits is a manifestation that female managers can manage productive assets to generate profitability. Female managers refrain from allocating unfavorable or consumptive assets that are likely to harm the business. Of course, the market or customers will increasingly trust this business because female managers have built a commitment to grow and make self-improvements and have a spirit of competitive advantage to this business produces good performance as well.

In line with a market-based view (MBV) emphasizes business performance which, tends to be determined by the unique position of the company's strategic behavior played by managers in responding to current market competition (Barney, 1991; Porter, 1990). The concept of competitiveness will only be meaningful if this concept is in place through competition. Without the competition, competitiveness will lose its importance (Lakhal, 2009; Munizu, 2019). In order not to lose meaning and miss the rhythm of competition, it is necessary to have the quality of intellectual capital and the quality of innovative behavior of managers so that business performance is good. Therefore, this study supports the hypothesis proposed by, (Al-ansari et al., 2013), (Örnek and Ayas, 2015), (Özmutaf et al., 2015), (Sumail and Abdullah, 2019) stated that the better the innovative behavior of female managers, the better the business performance. 
We claimed that a successful business is a manager who performs well through innovative roles, such as a woman manager. Female managers can grasp the meaning of the competition drum sound in the market through a process of innovation (Carrasco, 2014).

Female managers have a personal sense of competition, an entrepreneurial mentality, and a sense of curiosity or curiosity. It is a feature that a female manager innovative behavior to have competitiveness, strengthen self-confidence and improve performance. A female manager's curiosity tends to be immense when compared to the sense of entrepreneurial mentality. A highly competitive woman manager means that she sees life as a competitive ground in all aspects of life. The female managers compete with themselves. The existence of competitors is a driving force to foster enthusiasm, and no-one else. Therefore, a sense of competition must be interpreted as motivation to make changes, especially turning the catering business into a superior direction.

Innovation can drive a competitive advantage. We find that the most significant indicator in reflecting competitive advantage is valuable, then following indicators cannot be imitated, rare or unique and cannot be substituted. In this innovative role, the woman manager succeeded in creating meaningful product value. Consumers feel that excellent products such as taste, aroma, and texture are different from other products, which means that the female managers create a strategic product. The result is a value in taste, aroma, unique product texture, and business company atmosphere, and the environment has advantages over the same products from other companies. Therefore, the inherent value of competitive advantage will drive good business performance and quality. Thus, this study supports the hypothesis put forward by some previous researchers. For example, (Al-ansari et al., 2013), (Katarzyna, 2015), (Nadia et al., 2016) stated that the better the innovative behavior of female managers, the better the competitive advantage.

To obtain a competitive advantage from innovation to produce unique products that exceed competitors, such as designing flavors, aromas, and textures to the result of business performance are good. A female manager's capability can capture the market message on competitive advantages to maintain and encourage good business performance. One of the things that female managers do in managing a catering business is to differentiate products. Because the businesses are made from local raw materials for differentiate products. It is believed that female managers can differentiate products by creating taste, aroma, and texture and are unique so that these products become top of mind in consumers' heads (Pargaonkar, 2016). Of course, this business will get value from customers (customer value). Customer value portrays that customers feel there is more valuable than other companies. It arises because the emotional bonds are built between business people and customers.

The differentiation or uniqueness of catering products is the taste, aroma, and texture which tends to be rare in other food products. So the catering products tend to be difficult to substitute or replace so that this business performs well. This study supports the hypothesis proposed by (Davcik and Sharma, 2016), (Ejrami et al., 2016), (Wahyuni and $\mathrm{Ng}, 2012$ ) stated that the higher the competitive advantage, the higher the business performance.

A female manager's innovative behavior has an impact on the performance of the catering business, and it becomes a meaningful competitive advantage. Therefore, the 
hypothesis proposed in this study is acceptable, the higher the competitive advantage, the higher the catering business performance.

Empirical evidence shows that the role of competitive advantage is very significant (highly significant) between the influence of a manager's innovative behavior and business performance. It means that the better the female manager's innovative behavior, the better business advantage performance. It is because the innovative behavior of female managers found reality through the eyes of customers and customers, resulting in competitive innovation and good business performance. Therefore, the innovation produces a competitive advantage that can reduce the gap in customer needs or change the facts to suit customer needs. The innovation does not seem blind it always displays a sense of curiosity, a sense of competition, and have an entrepreneurial mind.

The motivation and commitment of a female manager can increase curiosity and can produce a useful result. Curiosity female managers always invite and guide employees to make positive and long-lasting innovations. A female manager and employees usually evaluate and improve the customers' tastes. Systems, processes, and workflows can all stagnate if they are not repaired and refined over time. In the catering business competition, a female manager's innovative behavior can produce more innovative products and have new product creation that can capture the customers' messages. She tries the best to provide fresh ideas to turn the company around according to customer needs. Competitive female managers know more about the customer's taste, and she learns and finds a new strategy for the catering business to be more successful. A female manager who has a high sense of competency are increasingly informed about the customers' tastes.

When competitors generate sizeable profits than the company, they have discovered new techniques to attract customers. When a female manager becomes active, creative, and focused, the employee unconsciously becomes someone who is always thinking about finding the best solution to satisfy customers. Having high motivation also makes female managers more successful in establishing the business. She is a hard worker. The catering business world needs a successful individual to win the competition.

In the catering business world, the obstacles, challenges, and problems seem to be undistinguished. By having the mentality and character, and a strong will to be successful, an entrepreneur can pass all of that smoothly. Therefore, we dare to say that a woman manager will be strong if she has an entrepreneurial mind. According to several successful entrepreneurs, strong willingness is one of the mandatory things that an entrepreneur musthave. Belief in one's abilities needs in running a catering business. An entrepreneur who has a character who believes in self-ability will be able to control doubts and anxieties in running the catering business (Dzogbenuku and Keelson, 2019). With high self-confidence, a woman manager determines to succeed in the catering business, because a successful person reflects confidence.

A woman manager who has an entrepreneurial mentality and character puts forward discipline (Clarke and Holt, 2019). It is because discipline is one of the characteristics an entrepreneur must-have. Disciplinary is also a reflection of a professional worker. So if female managers want to be successful in implementing the entrepreneurial mentality, it is appropriate for female managers to begin to discipline themselves so that the catering business runs and can continue to grow. By having a disciplined nature, female managers will no longer procrastinate on the work that is their responsibility as a woman manager 
who has a true and reliable entrepreneur mentality. Therefore, women managers who are entrepreneurs must have an unyielding spirit. Because in reality, sometimes the business that is carried out will not be as smooth as imagined, many unexpected events occur. When bad things happen to a business, like losses, this unyielding spirit is what is needed. Immediately get up and try again, let yesterday's failure be a valuable experience for female managers who have an entrepreneurial mentality. To become a woman manager who dares to take risks is a mental characteristic of a female manager and an entrepreneur's character. The female managers skilled is to reduce the business risks to make the company values the customers.

Indeed, most people think that the toughest part of innovation is to generate new ideas. After all, ideas are often represented by a shining bulb, that represents a blinding, terrible, and unexpected enlightenment. It is evidenced by the female managers who have successfully managed this business with delicious taste and competitive advantage. This achievement is achieved because it is valuable, cannot be imitated, rare or unique, and cannot be substituted to encourage good business performance. The implications of the innovative behavior of female managers who carry out innovative activities and competitive advantages have an impact on the good performance of the catering business.

\section{CONCLUSION}

For a business to have a competitive advantage in terms of taste, aroma, and texture, it requires managers who have innovative and qualified behavior, female managers. A female manager's innovative behavior does not only rely on the support of tangible assets. But it is much more meaningful if there is support for intangible assets such as intellectual capital. The better the intellectual capital, the better the female manager's innovative behavior. It can be said that the female managers' innovative behaviors are different from the male managers' innovative behaviors. The female managers' behavior can increase curiosity in a sense of competition and have an entrepreneurial spirit to compete for the business advantage.

This business becomes valuable in the market, tends to be difficult to imitate, rare, and difficult to substitute. Also, this business is unique in taste, aroma, texture, resulting in good business performance. This is evidenced by increased sales growth, strong market share, and increased profitability. As the research agenda in the future is to formulate a pattern of relationships between intellectual capital and competitive advantage.

\section{REFERENCES}

Achtenhagen, L., and Tillmar, M. (2013). Studies on women's entrepreneurship from Nordic countries and beyond. International Journal of Gender and Entrepreneurship, 5(1), 4-16.

Al-ansari, Y., Pervan, S., and Xu, J. (2013). Innovation and business performance of SMEs : the case of Dubai. Education, Business and Society: Contemporary Middle Eastern Issues, 6(3/4), 162-180.

Aramand, M. (2013). Women entrepreneurship in Mongolia: The role of culture on entrepreneurial motivation. Equality, Diversity and Inclusion, 32(1), 68-82. 
Barney, J. (1991). Firm Resources and Sustained Competitive Advantage. Journal of Management, $x x x(\mathrm{xxx}) \mathrm{xxx}-\mathrm{xxx}$.

Bellora, L., Guenther, T. W., and Thomas, W. (2013). Drivers of innovation capital disclosure in intellectual capital statements: Evidence from Europe. The British Accounting Review, 5(3), 35-46.

Bhardwaj, B. R. (2014). Impact of education and training on performance of women entrepreneurs: A study in emerging market context. Journal of Entrepreneurship in Emerging Economies, 6(1), 38-52.

Brinia, V. (2012). Men vs women; educational leadership in primary schools in Greece: an empirical study. International Journal of Educational Management, 26(2), 175-191.

Carrasco, I. (2014). Gender gap in innovation : an institutionalist explanation. Management Decision, 52(2), 410-424.

Chasaki, D. (2017). Entrepreneurial-minded learning in a freshman mini-project in Computing. ASEE Annual Conference and Exposition, Conference Proceedings, 2017-June, 26-37.

Chou, C. Y., Huang, C. H., and Lin, T. A. (2018). Organizational intellectual capital and its relation to frontline service employee innovative behavior: consumer value cocreation behavior as a moderator. Service Business, 12(4), 663-684.

Clarke, J. S., and Holt, R. (2019). Images of entrepreneurship: Using drawing to explore entrepreneurial experience. Journal of Business Venturing Insights, 11(December 2018).

Davcik, N. S., and Sharma, P. (2016). Marketing resources, performance , and competitive advantage: A review and future research directions. Journal of Business Research.

Demirbag, M., Tatoglu, E., Tekinkus, M., and Zaim, S. (2006). An analysis of the relationship between TQM implementation and organizational performance: Evidence from Turkish SMEs. Journal of Manufacturing Technology Management, 17(6), 829-847.

Diana, C., Sorin, M., Mirela, I., Laura, M., and Sabina, I. (2015). Creating Competitive Advantage in Coal Mining Industry in Romania: A New Challenge. Procedia Economics and Finance, 23(October 2014), 428-433.

Dzogbenuku, R. K., and Keelson, S. A. (2019). Marketing and entrepreneurial success in emerging markets: the nexus. Asia Pacific Journal of Innovation and Entrepreneurship, 13(2), 168-187.

Ejrami, M., Salehi, N., and Ahmadian, S. (2016). The Effect of Marketing Capabilities on Competitive Advantage and Performance with Moderating Role of Risk Management in Importation Companies. Procedia Economics and Finance, 36(16), 22-28.

Golemen, D. (2002). Emmotional Intelligence: Mengapa EI Lebih Penting daripada IQ, PT. Gramedia Pustaka Utama, Jakarta

Han, Y., and Li, D. (2015). Effects of intellectual capital on innovative performance The role of knowledge-based dynamic capability. Management Decision, 53(1), 40-56.

Harvey, M., Novicevic, M., and Breland, J. W. (2009). Global dual-career exploration and the role of hope and curiosity during the process. Journal of Managerial Psychology, 24(2), 178-197. 
Joshi, M., Cahill, D., Sidhu, J., and Kansal, M. (2012). Intellectual capital and financial performance : an evaluation of the Australian financial sector. Journal of Intellectual Capital, 14(2), 264-285.

Kamukama, N., Ahiauzu, A., and Ntayi, J. M. (2011). Competitive advantage: mediator of intellectual capital and performance. Journal of Intellectual Capital, 12(1), 152-164.

Kariv, D. (2012). "Off stage-on stage": men and women entrepreneurs leading change and business growth. Journal of Enterprising Communities: People and Places in the Global Economy, 6(2), 169-184.

Katarzyna, Ł. (2015). Development of Competitive Advantage of Small Innovative Firm How to Model Business Advice Influence within The Process? Procedia Economics and Finance, 23(October 2014), 487-494.

Kurnia, K. (2014). Imajinasi Picu Naluri Bisnis http://www.biskom.web.id/2014/10/20/kafi-kurnia-imajinasi-picu-naluri-bisnis.bwi.

Krugman, P. R. (1996). Making Sense Of The Competitiveness Debate. Massachusetts Institute of Technology. The Oxford Review of Economic Policy, 12(3), 17-25.

Lakhal, L. (2009). Impact of quality on competitive advantage and organizational performance. Journal of the Operational Research Society, 60(5), 637-645.

Lee, Y. G., Jasper, C. R., and Fitzgerald, M. A. (2010). Gender Differences in Perceived Business Success and Profit Growth Among Family Business Managers. J Fam Econ Iss, 31, 458-474.

López-ruiz, V., Alfaro-navarro, J., and Nevado-peña, D. (2014). Knowledge-city index construction : An intellectual capital perspective. Expert Systems with Applications.

Maditinos, D., Chatzoudes, D., Tsairidis, C., and Theriou, G. (2011). The impact of intellectual capital on firms' market value and financial performance. Journal of Intellectual Capital, 12(1), 132-151.

Maxfield, S., Shapiro, M., Gupta, V., and Hass, S. (2010). Gender and risk : women , risk taking and risk aversion. Gender in Management: An International Journal, 25(7), 586-604.

Mondal, A., and Ghosh, S. K. (2012). Intellectual capital and financial performance of Indian banks. Journal of Intellectual Capital, 13(4), 515-530.

Nadia, N., Aziz, A., and Samad, S. (2016). Innovation and Competitive Advantage: Moderating Effects of Firm Age in Foods Manufacturing SMEs in Malaysia. Procedia Economics and Finance, 35(October 2015), 256-266.

Namvar, M., Fathian, M., Akhavan, P., and Gholamian, M. R. (2010). Exploring the impacts of intellectual property on intellectual capital and company performance The case of Iranian computer and electronic. Management Decision, 48(5), 676-697.

Nikina, A., Shelton, L. M., and LeLoarne, S. (2015). An examination of how husbands, as key stakeholders, impact the success of women entrepreneurs. Journal of Small Business and Enterprise Development, 22(1), 38-62.

Örnek, A. Ş., and Ayas, S. (2015). The Relationship between Intellectual Capital, Innovative Work Behavior and Business Performance Reflection. Procedia - Social and Behavioral Sciences, 195, 1387-1395.

Özmutaf, N. M., Aktekin, E., Ergani, B., and Çıta, K. (2015). The Effects of Innovative Features of Women Managers on their Business Performance: The Food Exporter 
Companies in Aegean Region Sample. Procedia - Social and Behavioral Sciences, 195, 220-229.

Pargaonkar, Y. R. (2016). Leveraging patent landscape analysis and IP competitive intelligence for competitive advantage. World Patent Information, 45, 10-20.

Porter, M. E. (1990). Book Review: The Competitive Advantage of Nations. Journal of Management (Vol. 17), 55-65.

Solimun., Adji A. R., dan Nurjannah. (2017). Metode Statistika Multivariat: pemodelan Persamaan Struktural (SEM) Pendekatan WarpPLS. UB Press Malang.

Sölvell, Ö. (2015). The Competitive Advantage of Nations 25 years - opening up new perspectives on competitiveness. Competitiveness Review, 25(5), 471-481.

Subramaniam, M., and Youndt, M. A. (2005). The Influence Of Intellectual Capital On The Types Of Innovative Capabilities. Academy of Management Journal, 48(3), 450-463.

Sumail, L. O., and Abdullah, S. (2019). Innovative Behavior And Emotional Intelligence Of Managers In Managing A Catering Business. Jurnal Manajemen, 23(2), 290-301.

Sweida, G. L., and Reichard, R. J. (2013). Gender stereotyping effects on entrepreneurial self-efficacy and high-growth entrepreneurial intention. Journal of Small Business and Enterprise Development, 20(2), 296-313.

Sydler, R., Haefliger, S., and Pruksa, R. (2013). Measuring intellectual capital with financial figures : Can we predict firm profitability? European Management Journal, 12(5) 6782

Valentine, S., Godkin, L., Page, K., and Rittenburg, T. (2009). Gender and ethics. Gender in Management: An International Journal, 24(2), 112-127.

Valentine, S., Godkin, L., Page, K., Rittenburg, T., Page, K., and Rittenburg, T. (2009). Gender and ethics Ethical judgments, ethical intentions, and altruism among healthcare professionals. Gender in Management: An International Journal, 24(2), $112-130$.

Wahyuni, S., and Ng, K. K. (2012). Historical outlook of Indonesian competitiveness : past and current performance. Competitiveness Review: An International Business Journal, 22(3), 207-234.

Wang, Z., Wang, N., and Liang, H. (2014). Knowledge sharing, intellectual capital and firm performance. Management Decision, 52(2), 230-258.

Yaseen, S. G., Dajani, D., and Hasan, Y. (2016). Computers in Human Behavior The impact of intellectual capital on the competitive advantage: Applied study in Jordanian telecommunication companies. Computers in Human Behavior, 62, 168-175. 